\title{
THE EFFECT OF INFORMATION SYSTEM, SERVICE QUALITY AND HAJJ OFFICER ON TRUST AND ITS IMPACT ON SATISFACTION OF HAJJ PILGRIM OF ACEH
}

\author{
Zul Khairiyati,Nurdasila Darsono and A.Sakir \\ Management Department,Syiah Kuala University, Indonesia \\ http://doi.org/10.35409/IJBMER.2020.3181
}

\begin{abstract}
This study tries to examine the effect of information systems, service quality and hajj pilgrims on trust and their impact on the satisfaction of Aceh pilgrims. The sample is 200 respondents to fit the requirement of the the Structural Equation Modeling (SEM) as a testing method. The 200 respondents are the people from the Aceh hajj pilgrims who performed the Hajj in 2018, who are sufficiently representative to be studied.. This study results Information system affects trust, Service Quality affects trust, Hajj officer affects trust, Information system affects satisfaction, Service quality affects trust, Hajj officer affects trust, Trust affects satisfaction, Information system affects satisfaction through trust, Service quality affects satisfaction through trust, and Hajj officer affects satisfaction through trust. These findings give the contribution to update the causality theories from the previous, and give more views for practical leaders especially who regulate the Hajj. The novelty resides in the combination of the previous models, and this uses a new object. The limitation lies in the scope of variables and constructs. The regulators need to pay attention more to the use of information system, maintain the service quality, and contrul the Hajj officers.
\end{abstract}

Keyword: Information System, Service Quality, Hajj Officers, Trust, Satisfaction.

\section{INTRODUCTION}

The successful implementation of the hajj involved many parties, in addition to the relevant institutions dealing with hajj, as well as other parties. The development of the hajj service in the reform period was marked by the enactment of Law (Law) number 17 of 1999. Over time, the Act continued to change according to needs and circumstances. At present, in the Organization of Hajj, the Ministry of Religion refers to Law No. 13/2008 concerning the Implementation of Hajj which has been amended in Law (Law) No. 34/2009 concerning Hajj Implementation mandating that as Hajj organizers, the government has an obligation to manage, carrying out the Hajj.

The Directorate General of Hajj and Umrah Management (PHU) as the policy maker and technical standardization in the field of PHU, strives to continuously improve the quality of the Hajj. The government is also trying to reform various aspects of guidance, protection and service in order to realize the satisfaction of the pilgrims in carrying out their worship. The satisfaction 


\section{International Journal of Business Management and Economic Review}

Vol. 3, No. 03; 2020

ISSN: 2581-4664

of pilgrims in carrying out the pilgrimage plays an important role in efforts to provide a real picture in order to improve the management of the pilgrimage services. Satisfaction is a person's feelings after comparing the performance of a product or service in accordance with his expectations. (Lupiyoadi, 2013).

One of the factors determining the satisfaction of pilgrims is the trust of pilgrims in the implementation of the pilgrimage. According to (Akbar and Parvez, 2009) there is trust when someone can convince other parties through the integrity they have. Trust has a significant impact on consumer satisfaction (Kassim et al., 2012).

In increasing the satisfaction of pilgrims, every organization, both government and private, must have one factor, namely relevant resources which in this case are pilgrims. In the science of marketing management, people (people) / (hajj officers) are interpreted as actors who all play an important role in the presentation of services so as to influence the buyer's perception. Officers accompanying the pilgrims are those who are assigned to serve and guide the pilgrims in a flying group (kloter) from the beginning of embarkation to the debarkation of the homeland.

People in this study are pilgrims who influence customer satisfaction (Anggrariani and Wardana, 2016). The same thing was conveyed by (Bisri and Setianingrum, 2018) whose research results showed that People had a positive impact on customer satisfaction. This means that with the presence of hajj officers who have a good attitude is very influential on the satisfaction of pilgrims.

In addition to hajj officers, service quality is also a determining factor in the satisfaction of pilgrims. If the service to the Jamaah is good and in accordance with the expectations of the pilgrims, the pilgrims will be satisfied (Lupiyoadi and Hamdani, 2011). Quality of service remains one of the determinants of traditional satisfaction. The relationship between the two constructs can be traced back to the literature on marketing and consumer behavior (Kasiri et al., 2017). The use of applications or information systems is also a factor that can affect the satisfaction of pilgrims. Technology is the development and application, machines, tools, materials and processes to help humans solve every problem. Furthermore, information as a result of processing and manipulation and structuring / organizing a group of data which has a value of knowledge for its users. (Hall, 2011).

\section{LITERATURE}

\section{Satisfaction}

Satisfaction can be interpreted as an effort to fulfill something and make it fulfilled. Customer satisfaction is the level of feeling of someone who compares the expectations he wants to achieve after feeling the performance results obtained by (Kotler and Keller, 2018). (Parasuraman, Zeithaml and Berry, 1988) proposed a specific transaction conceptualization of the relationship of service quality and customer satisfaction. Overall customer dissatisfaction or satisfaction with a transaction depends on their evaluation of the price and quality of the product or service provided. (Ngniatedema et al., 2015) explained that service customization is an important factor for customers when making judgments about their satisfaction. User satisfaction is the result of evaluations based on experience using information systems (Setyo and Rahmawati, 2015). According to (Zeithaml, Bitner and Gremler, 2018) customer satisfaction is a product or service that is evaluated by consumers in order to meet their needs and expectations. Kotler \& Armstrong (2014) revealed that indicators measure customer satisfaction, including: (1) 


\section{International Journal of Business Management and Economic Review}

Vol. 3, No. 03; 2020

ISSN: 2581-4664

Products / services that provide benefits, (2) Communication with customers, (3) Services as desired, (4) Costs incurred according to customer expectations, and (5) Ease of transactions.

\section{Trust}

Trust is a belief in transacting between one party competing with another party by being able to fulfill all obligations as expected (Chulaifi and Setyowati, 2018). (Siagian and Cahyono, 2014) revealed that trust is a belief of the intentions and behavior of certain parties towards other parties. (Kotler and Keller, 2012) provided an understanding that the definition of trust is the extent to which a company's willingness depends on its business partners. There are several factors of trust that depend between individuals and organizations, for example, honesty, integrity, competence and tolerance of a company (Deng et al., 2010). Trust is trust in partners who are in a relationship, for every service business that does not exist full certainty and risk then uninformed between the parties in a relationship then trust becomes very important role (Halik, 2016). Consumer confidence is concluded as the expectation of consumers regarding service providers that can be trusted and relied upon to fulfill their promises. trust indicators according to (Chulaifi and Setyowati, 2018) namely (1) trust in employee services (2) trust in the facilities provided (3) trust in security guarantees (4) trust in reputation (4) trust in responsibility (5) Trust in good faith.

\section{Hajj Officer (People)}

People are part of the service marketing mix. People are defined as services. theoretically, people are interpreted as all actors in the presentation of services that play an important role in a company that affects the perception of buyers. The people element consists of company employees and consumers. All employees' attitudes and actions, such as how they are dressed and how they look have an effect on the success of service delivery (Kotler and Keller, 2018). (Zeithaml, Bitner and Gremler, 2018) explain that buyer perceptions can be greatly influenced by all those who play a role in the service department, that is, company members, customers, as well as other customers in the service environment. People are service providers that can have an impact on the quality of services provided (Lupiyoadi, 2013). According to (Zeithaml, Bitner and Gremler, 2018) employee capabilities are divided into two, namely (1) Service people. In service organizations, People indicators according to (Simamora, 2004), (Kotler and Keller, 2018), namely: (1) Competence, (2) Courtesy, (3) Selective (4) Communicative and (5) Reliability.

\section{Service Quality}

According to the State Administration Agency (2009: 56) service is a benchmark used in assessing the quality of service is a commitment from the quality service provider to the customer ". (Fajri and Ma'ruf, 2018) explained that service is a process to meet the needs of consumers from various activities directly. Quality of service is a measure of how good and good the services provided are able to match the expectations of the customer. (Wijaya, 2018); (Tjiptono, 2017). Service quality as a comparison of expectations with actual performance perceptions of services (Unidha, 2017). The above theory provides understanding of service as a company activity according to expectations to increase excellence and fulfill the wishes, expectations and satisfaction of customers. Service quality indicators are taken from several servqual dimensions according to (Parasuraman, Zeithaml and Berry, 1988), namely (1) Costs 


\section{International Journal of Business Management and Economic Review}

Vol. 3, No. 03; 2020

ISSN: 2581-4664

and services, (2) Office facilities (3) Appearance of officers (4) Service procedures (5) Time of completion, (6) ) Officer Responsiveness, (7) Emotional Relations (8) Company attention to employee knowledge, (9) Officer Attention to Customers (10) Understanding Customer Problems.

\section{Information Systems (SI)}

(Kadir, 2014) argued that information systems are defined as a series of formal procedures in classifying, and processing data into information, and distributed to users. Information system, is a data processing system consisting of several manual or computer components and is integrated with each other in storing, collecting, and managing data (Diana and Setiawati, 2011); (Laudon and Laudon, 2014); (Rainer, Prince and Cegielski, 2017). All technologies used to collect, process and disseminate information are definitions of information systems. The indicators measured according to (Diana and Setiawati, 2011); Laudon 2014; Rainer and Cegielski, 2011) are : (1) SI Intensity (2) Availability of Experts (3) Investment in SI (4) Ease of exchanging SI (5) Ease of access to cooperation.

\section{Research Hypothesis}

From the literatures and facts happened, authors formulate the research model with hypothesis as follows.

$\mathrm{H} 1$ : Information system affects trust

$\mathrm{H} 2$ : Service Quality affects trust

H3 : Hajj officer affects trust

H4 : Information system affects satisfaction

H5 : Service quality affects trust

H6 : Hajj officer affects trust

H7 : Trust affects satisfaction

H7 : Information system affects satisfaction through trust

$\mathrm{H} 7$ : Service quality affects satisfaction through trust

H7 : Hajj officer affects satisfaction through trust

\section{METHOD}

This research is conducted on Aceh pilgrims while the variables are research IS information systems, service quality, hajj officers, trust and satisfaction of Aceh hajj pilgrims. The sample in this study is 200 respondents, this suits for the requirement of using Structural Equation Modeling (SEM) to test the research model. The 200 respondents are thepeople from the Aceh hajj pilgrims who performed the Hajj in 2018, who are sufficiently representative to be studied. The data is collected using questionnaires. Respondents aswer the question based on the likert scale.

\section{RESULT}

\section{Model and Data Test}

The Measurement Scale uses an interval scale in the form of a Likert scale based on five stretches. 
Vol. 3, No. 03; 2020

ISSN: 2581-4664

Table 1. Validity and Reliability

\begin{tabular}{|c|c|c|c|c|c|c|}
\hline Variable & Item & $\begin{array}{l}\text { Loading } \\
\text { Factor }\end{array}$ & CR & VE & $\begin{array}{l}\text { Discriminant } \\
\text { Validity }\end{array}$ & Remark \\
\hline $\begin{array}{l}\text { Information } \\
\text { Systems (X1) }\end{array}$ & $\begin{array}{l}\mathrm{X} 11 \\
\mathrm{X} 12 \\
\mathrm{X} 13 \\
\mathrm{X} 14\end{array}$ & $\begin{array}{l}0.710 \\
0.591 \\
0.842 \\
0.836\end{array}$ & 0.84 & 0.57 & 0.75 & $\begin{array}{l}\text { Valid dan } \\
\text { Reliable }\end{array}$ \\
\hline $\begin{array}{l}\text { Service quality } \\
\text { (X2) }\end{array}$ & $\begin{array}{l}\mathrm{X} 21 \\
\mathrm{X} 24 \\
\mathrm{X} 25 \\
\mathrm{X} 26 \\
\mathrm{X} 27 \\
\mathrm{X} 210\end{array}$ & $\begin{array}{l}0.812 \\
0.827 \\
0.669 \\
0.612 \\
0.867 \\
0.799\end{array}$ & 0.90 & 0.59 & 0.77 & $\begin{array}{l}\text { Valid dan } \\
\text { Reliable }\end{array}$ \\
\hline $\begin{array}{l}\text { Hajj Officer } \\
(\mathrm{X} 3)\end{array}$ & $\begin{array}{l}\mathrm{X} 31 \\
\mathrm{X} 32 \\
\mathrm{X} 33 \\
\mathrm{X} 34 \\
\end{array}$ & $\begin{array}{l}0.747 \\
0.777 \\
0.785 \\
0.703 \\
\end{array}$ & 0.84 & 0.57 & 0.75 & $\begin{array}{l}\text { Valid dan } \\
\text { Reliable }\end{array}$ \\
\hline $\begin{array}{l}\text { Trust } \\
\text { (Y) }\end{array}$ & $\begin{array}{l}\mathrm{Y} 1 \\
\mathrm{Y} 2 \\
\mathrm{Y} 3 \\
\mathrm{Y} 5 \\
\end{array}$ & $\begin{array}{l}0.547 \\
0.832 \\
0.894 \\
0.677 \\
\end{array}$ & 0.83 & 0.56 & 0.75 & $\begin{array}{l}\text { Valid dan } \\
\text { Reliable }\end{array}$ \\
\hline $\begin{array}{l}\text { Satisfaction } \\
\text { (Z) }\end{array}$ & $\begin{array}{l}\mathrm{Z1} \\
\mathrm{Z} 2 \\
\mathrm{Z} 3 \\
\mathrm{Z} 4 \\
\mathrm{Z} 5 \\
\end{array}$ & $\begin{array}{l}0.754 \\
0.843 \\
0.663 \\
0.79 \\
0.721 \\
\end{array}$ & 0.87 & 0.57 & 0.76 & $\begin{array}{l}\text { Valid dan } \\
\text { Reliable }\end{array}$ \\
\hline
\end{tabular}

Based on the data shown in Table 4.10 above, it describesabout the information system (X1), service quality, Hajj officer (X3), pilgrim trust $(\mathrm{Y})$ and pilgrim satisfaction $(\mathrm{Z})$. These five variables have a construct reliability value (CR) greater than 0.70 , so it reveals that the data is reliable. Meanwhile VE values obtained above 0.50 are required. Then the data is valid and reliable constructively. The discriminant validity value is interpreted by comparing the correlation values between constructs as shown below. 


\section{International Journal of Business Management and Economic Review}

Vol. 3, No. 03; 2020

ISSN: 2581-4664

Table 2. Correlation

\begin{tabular}{|l|l|l|l|l|}
\hline & & & Estimate & $\begin{array}{l}\text { Discriminant } \\
\text { Validity }\end{array}$ \\
\hline Information_System_X1 & $\langle-->$ & Servic_Quality_X2 & .014 & 0.75 \\
\hline Information_System_X1 & $<-->$ & Trust_Y & .119 & 0.77 \\
\hline Trust_Y & $<-->$ & Satisfaction_Z & .266 & 0.75 \\
\hline Hajj_Officer_X3 & $<-->$ & Satisfaction_Z & .095 & 0.77 \\
\hline Service_Quality_X2 & $<-->$ & Hajj_Officer_X3 & .090 & 0.76 \\
\hline
\end{tabular}

The results above show that the value of the correlation estimate for between constructs is far below the value of discriminant validity. These results provide evidence that all variables tested are unique and able to express all the phenomena measured.

Table 3. Goodness of Fit

\begin{tabular}{|l|l|l|l|}
\hline Goodness offit index & Cut of Value & Result & Remark \\
\hline X2-Chi-square & Expected to be small & 235.820 & Good \\
GFI & $>0.90$ & 0.910 & Good \\
AGFI & $>0.90$ & 0.880 & Received marginal \\
TLI & $>0.95$ & 0.983 & Good \\
CFI & $>0.95$ & 0.987 & Good \\
RMSEA & $<0.08$ & 0.027 & Good \\
CMIN/DF & $<2.0$ & 1.145 & Good \\
\hline
\end{tabular}

After making modifications to improve the marginal model, the final results of the model suitability test show a good model where the chi-square value has been smaller than before, then the GFI and AGFI values have been above 0.90, then TLI and CFI have been>0.95 and the probability is already>0.05. Therefore it states that the model in this study has fulfilled SEM assumptions and is suitable for use.

\section{Hypothesis Test}

Hypothesis testing is determined through two stages namely directly and indirectly shown in the following SEM image 


\section{International Journal of Business Management and Economic Review}

Vol. 3, No. 03; 2020

ISSN: 2581-4664

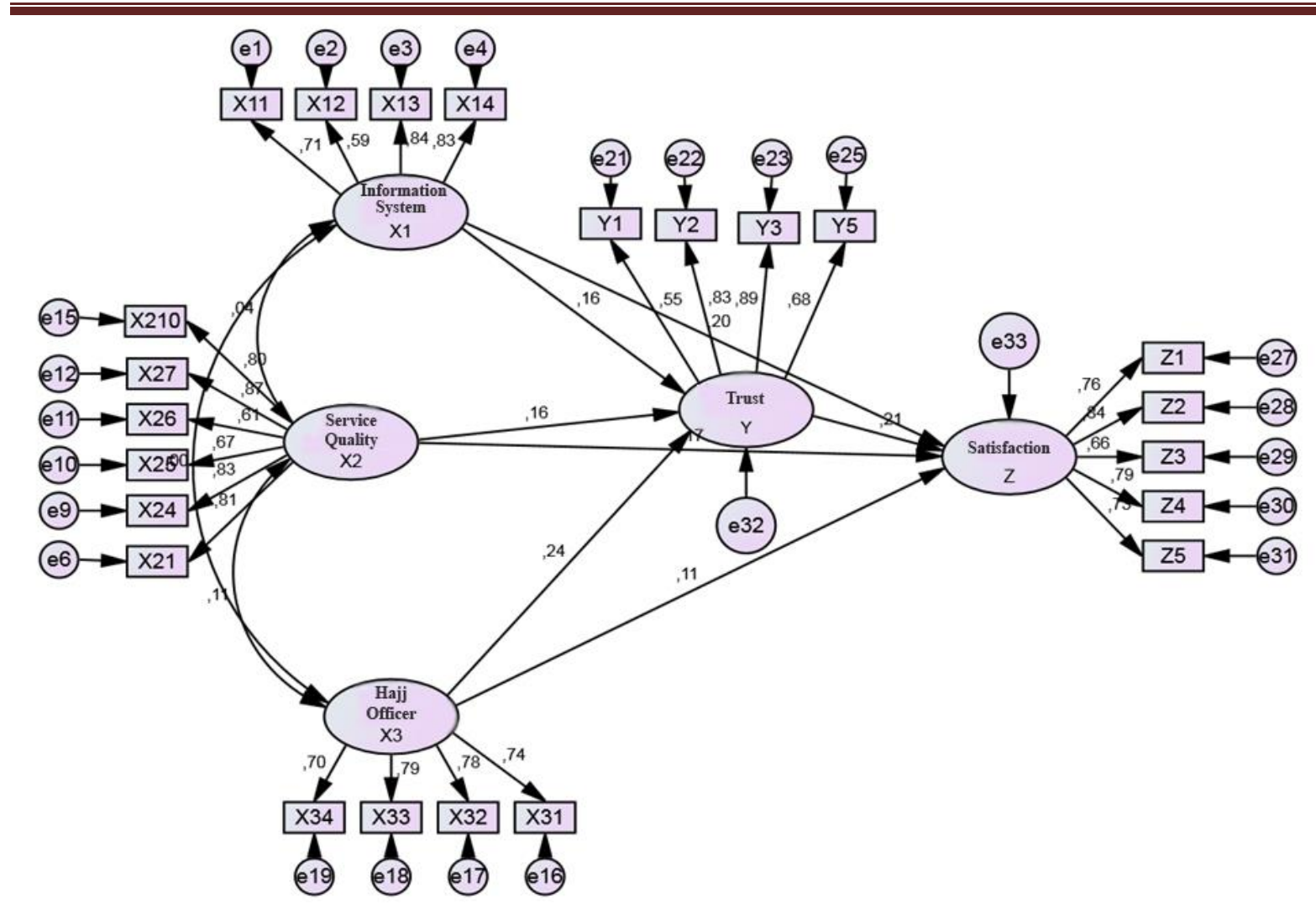

Figure 1. SEM Test Result

Table 3. Hypothesis Test Result

\begin{tabular}{|c|c|c|c|c|c|c|c|}
\hline Variable & & Variable & Estimate & $\begin{array}{l}\text { Std } \\
\text { Estimate }\end{array}$ & S.E & C.R & $\mathbf{P}$ \\
\hline Trust_Y & $<--$ & Information_System_X1 & .114 & .158 & .058 & 1.965 & .049 \\
\hline Trust_Y & $<--$ & Service Quality_X2 & .118 & .164 & .056 & 2.087 & .037 \\
\hline Trust_Y & $<--$ & Hajj_Officer_X3 & .180 & .239 & .064 & 2.822 & .005 \\
\hline Satisfaction_Z & $<--$ & Hajj_Officer_X3 & .112 & .108 & .084 & 1.333 & .183 \\
\hline Satisfaction_Z & $<--$ & Trust_Y & .292 & .211 & .118 & 2.476 & .013 \\
\hline Satisfaction_Z & <-- & Service_Quality_X2 & .172 & 174 & .076 & 2.265 & .024 \\
\hline Satisfaction_Z & $<--$ & Information_System_X1 & .197 & .196 & .079 & 2.477 & .013 \\
\hline
\end{tabular}

\section{H1 : The Effect of Information System on Trust}

The research results a C.R value $1.965>1.95$ at a probability level $0.049<0.05$ as required. This result means that the information system has a direct and significant effect on the trust of 
Vol. 3, No. 03; 2020

ISSN: 2581-4664

Aceh pilgrims. This resultis supported by the research of (Kassim et al., 2012)and(Santa, MacDonald and Ferrer, 2018); (Lu, Wang and Hayes, 2012); (Widodo, Dwi and Nurchayati, 2016). This resultexplains that the use of information systems in the organization of Hajj and Umrah namely SISKOHAT and Smart Hajj Application will greatly assist the pilgrims in obtaining information and facilitate pilgrims in the process of performing the pilgrimage, starting from initial registration up to the holy land and arriving back at homeland. Pilgrims will be more comfortable with a good information system as to give confidence to pilgrims.

\section{H2 : the Effect of Service Quality on the Belief of Jamaat}

The resultobtains a C.R value of 2.087 or $>1.95$ and a probability value 0.037 or $<0.05$ as required. With this we can conclude the quality of service directly and significantly influence the trust of Aceh pilgrims. This result suggests that the quality of services provided to Aceh hajj pilgrims by hajj officers will greatly influence the beliefs of hajj pilgrims in carrying out their hajj. Improving the quality of good service will give satisfaction to worshipers. The result of this study is supportedwith teh research conducted by (Santa, MacDonald and Ferrer, 2018); (Rafiqah et al., 2018) and (Unidha, 2017) which stated that service quality directly influences customer trust.

\section{H3 : The Effect of Hajj Officer on Trust}

This hypothesis has a C.R value of 2.822 or $>1.95$ and a probability value 0.005 or $<0.05$. It decleares that the hajj officer directly and significantly influence the trust of the Aceh Hajj pilgrims. The buyer perception can be strongly influenced by all those who play a part in the service, namely company members, customers, as well as other customers in the service environment. This means that the role of people in this case is the pilgrimage determines the trust of the Aceh pilgrims in carrying out the pilgrimage. Attitudes and treatment of officers to pilgrims largely determine the level of their trust, how officers can treat pilgrims properly and in accordance with the expectations of pilgrims themselves.

\section{H4 : The Effect of Information System on Satisfaction}

This hypothesis testprovides a C.R value 2.477 or $>1.95$ and a probability value 0.013 or $<0.05$. This means that the information system directly and significantly affects the satisfaction of Aceh pilgrims. The use of information technology in the implementation of the Hajj and Umrah namely SISKOHAT and Smart Hajj Application will greatly assist the pilgrims in getting information and facilitate pilgrims in the process of performing the pilgrimage, starting from initial registration up to the holy land and arriving back at homeland. This resultis also supported with the previous research of (Santa, MacDonald and Ferrer, 2018); (Lu, Wang and Hayes, 2012); (Widodo Agus et al., 2012); (Veeramootoo, Nunkoo and Dwivedi, 2018); (Kassim et al., 2012).

\section{H5 : The Effect of Service Quality on Satisfaction}

This hypotesis testresults a C.R value of 2.265 or> 1.95 and a probability value of 0.024 or $<0.05$. Hereby declares that the information system directly and significantly influences the satisfaction of Aceh pilgrims. When the quality of service provided by the officer is good, it will greatly affect the satisfaction of the pilgrims. 


\section{International Journal of Business Management and Economic Review}

Vol. 3, No. 03; 2020

ISSN: 2581-4664

This study is supported withthe research conducted by (Kasiri et al., 2017); (Khoo, Ha and McGregor, 2017); (Nunkoo et al., 2017), that stated service quality has a positive influence on customer satisfaction.(Rasyid, 2017); (Santa, MacDonald and Ferrer, 2018); (Veeramootoo, Nunkoo and Dwivedi, 2018); (Kasiri et al., 2017) and (Markus, 2005) explained that the assessment of satisfaction and service quality comes from a comparison between what is expected and what is received, consumer assessment of service quality is guided by a combination of the expectations of satisfaction.

\section{H6 : The Effect of Hajj Officer on Satisfaction}

This hypothesis provides a C.R 1.333 or $<1.95$ and the probability value 0.183 or $>0.05$. Thus it reveals that hajj officerdoes not affect the satisfaction of Aceh pilgrims. This result indicates the satisfaction of pilgrims is not influenced by the presence of officers, but the quality of services provided by officers who determine whether pilgrims are satisfied or not. This resultis rejected with the previous research by (Anggrariani and Wardana, 2016); (Bisri and Setianingrum, 2018) which resultedthe people have a positive and significant effect on customer satisfaction.

\section{H7 : The Effect of Trust on Satisfaction}

This hypothesistest results a C.R value of 2.476 or $>1.95$ and a probability value 0.013 or $<0.05$. Thus, it describes that the trust of pilgrims has a direct and significant effect on the satisfaction of Aceh pilgrims. With the desire and trust will solve all the problems of organizing the pilgrimage and all information provided by officers will affect the level of satisfaction of Aceh pilgrims. This resultis supported with previous research by (Kassim et al., 2012); (Santa, MacDonald and Ferrer, 2018).

\section{H8 : The Effect of Information Systems on Satisfaction through Trust}

This hypothesistest provides the trust variable is as a full mediation. It accepts the hypothesis that trust mediates the relationship of information systems with the satisfaction of Aceh hajj pilgrims. Thisexplains that the use of information technology such as SISKOHAT and Smart Hajj Application will indirectly affect the satisfaction of the Aceh pilgrims, through the trust of the pilgrims. This resultis supported with previous research by, (Kassim et al., 2012); (Widodo, Dwi and Nurchayati, 2016).

\section{H9 : The Effect of Service Quality on Satisfaction through Trust}

The hypothesis provides the trust variable as a full mediation. The resultaccepts the hypothesis that trust mediates the relationship of service quality with satisfaction of Aceh hajj pilgrims. This results of this study is supported with previous research by (Santa, MacDonald and Ferrer, 2018) which stated that the quality of service has a direct impact on user trust and then trust will produce satisfaction.

\section{H10 : The Effect of Service Quality on Satisfaction through Trust}

This hypothesis provides the trust variable as a partial mediation. The resultaccepts the hypothesis that trust mediates the effect of Hajj Officeron satisfaction of Aceh Hajj pilgrims. 


\section{International Journal of Business Management and Economic Review}

Vol. 3, No. 03; 2020

ISSN: 2581-4664

\section{Research Implication}

Based on the result noted, the information system, service quality and hajj officers have a direct influence on the trust of Aceh pilgrims. Furthermore, information systems and service quality also have a direct influence on the satisfaction of Aceh hajj pilgrims, while hajj officer does not directly influence the satisfaction of Aceh hajj pilgrims. Furthermore trust has a direct influence on the satisfaction of Aceh pilgrims.

Based on indirect hypothesis testing it is known that the influence of the information system on the satisfaction of Aceh pilgrims is indirectly mediated by the trust of the pilgrims, as a full mediation. Furthermore, the influence of service quality on the satisfaction of Acehpilgrims is indirectly mediated by the trust of the pilgrims, as a full mediation. While trust also mediates the influence of pilgrims on pilgrimage satisfaction, as a partial mediation. This is due to the fact that Aceh pilgrims pay more attention to the quality of services and information systems in forming their trust and satisfaction. Therefore in this case the pilgrims believe in Aceh hajj officers onlythrough the trust that can be built by them.

\section{CONCLUSION}

This study results Information system affects trust, Service Quality affects trust, Hajj officer affects trust, Information system affects satisfaction, Service quality affects trust, Hajj officer affects trust, Trust affects satisfaction, Information system affects satisfaction through trust, Service quality affects satisfaction through trust, and Hajj officer affects satisfaction through trust. These findings give the contribution to update the causality theories from the previous, and give more views for practical leaders especially who regulate the Hajj. The novelty resides in the combination of the previous models, and this uses a new object. The limitation lies in the scope of variables and constructs. The regulators need to pay attention more to the use of information system, maintain the service quality, and contrul the Hajj officers.

\section{REFERENCES}

Akbar, M. M. and Parvez, N. (2009) 'Impact of Service Quality, Trust, and Customer Can Service Quality, Trust, and Customer Satisfaction on Customers Loyalty Satisfaction Engender Customers Loyalty?', ABAC Journal, 29(1), pp. 24-38.

Anggrariani, R. and Wardana, A. (2016) 'Pengaruh Bauran Pemasaran Jasa Terhadap Kepuasan Konsumen Liquid Bar Bandung', e-Proceeding of Management, 3(1), pp. 655-666.

Bisri and Setianingrum, H. W. (2018) 'Analisis Pengaruh Faktor Bauran Pemasaran Jasa Terhadap Kepuasan Nasabah (Studi Kasus BNI Syariah Kantor Cabang Cinere)', MONETER Jurnal Akuntansi dan Keuangan, 5(1), pp. 63-73. doi: https://doi.org/10.31294/moneter.v5i1.3384.

Chulaifi, M. I. and Setyowati, E. (2018) 'Pengaruh Kualitas Pelayanan, Persepsi Harga Dan Kepercayaan Terhadap Kepuasan Konsumen Jasa Travel Umrah Dan Haji Pada Pt. Sebariz Warna Berkah Di Surabaya', Jurnal Hasil Penelitian LPPM Untag Surabaya, 3(1), pp. 40-54. Available at: jurnal.untag-sby.ac.id/index.php/jhp17.

Deng, Z. et al. (2010) 'Understanding customer satisfaction and loyalty: An empirical study of mobile instant messages in China', International Journal of Information Management, 30(4), pp. 289-300. doi: https://doi.org/10.1016/j.ijinfomgt.2009.10.001. 


\section{International Journal of Business Management and Economic Review}

Vol. 3, No. 03; 2020

ISSN: 2581-4664

Diana, A. and Setiawati, L. (2011) Sistem informasi akuntansi: perancangan, proses, dan penerapan. Banda Aceh: Andi Publisher.

Fajri, D. and Ma'ruf, J. J. (2018) 'Pengaruh Social Media Marketing Dan Promosi Harga Terhadap Kepuasan Konsumen Dan Pengalaman Konsumen Sebagai Variabel Mediasi Pada Maskapai Penerbangan Airasia Di Banda Aceh', Jurnal Ilmiah Mahasiswa Ekonomi Manajemen, 3(3), pp. 33-48.

Halik, A. (2016) 'Pengaruh Bauran Pemasaran Jasa, Kualitas Layanan Dan Nilai Religiusitas Terhadap Kepercayaan Nasabah Dan Imlikasinya Pada Komitmen Nasabah Bank Umum Syariah Di Wilayah Gerbang Kertasusila Jawa Timur', Jurnal Hasil Penelitian LPPM Untag Surabaya, 1(1), pp. 123-148.

Hall, J. A. (2011) Accounting Information Systems. 7th edn. United States: South-Western College Pub.

Kadir, A. (2014) Pengenalan Sistem Informasi. Revisi. Yogyakarta: Andi.

Kasiri, L. et al. (2017) 'Integration of standardization and customization: Impact on service quality, customer satisfaction, and loyalty', Journal of Retailing and Consumer Services, 35, pp. 91-97. doi: 10.1016/j.jretconser.2016.11.007.

Kassim, E. S. et al. (2012) 'Information system acceptance and user satisfaction: The mediating role of trust', in International Conference on Asia Pacific Business Innovation and Technology Management. Malaysia: Elsevier Ltd, pp. 412-418. doi: 10.1016/j.sbspro.2012.09.1205.

Khoo, S., Ha, H. and McGregor, S. L. T. (2017) 'Service quality and student/customer satisfaction in the private tertiary education sector in Singapore', International Journal of Educational Management, 31(4), pp. 430-444. doi: https://doi.org/10.1108/IJEM-09-2015-0121.

Kotler, P. and Keller, K. L. (2012) Marketing Management. 14th edn. London, UK: Pearson Education.

Kotler, P. and Keller, K. L. (2018) Marketing Management, Global Edition. 15th editi. Harlow, United Kingdom: Pearson.

Laudon, K. C. and Laudon, J. P. (2014) Management Information SystemsManaging the Digital Firm. 13th edn. England: Pearson Education Limited.

Lu, J., Wang, L. and Hayes, L. A. (2012) 'How do technology readiness, platform functionality and trust influence C2C user satisfaction?', Journal of Electronic Commerce Research, 13(1), pp. $50-69$.

Lupiyoadi, R. (2013) Manajemen Pemasaran Jasa Berbasis Kompetensi. 3rd edn. Jakarta: Salemba Empat.

Lupiyoadi, R. and Hamdani, D. A. (2011) Manajemen pemasaran jasa. Ed. 2. Jakarta: Salemba Empat.

Markus, M. (2005) Perpajakan Indonesia : suatu pengantar. Jakarta: Gramedia Pustaka Utama. Ngniatedema, T. et al. (2015) 'Late customization strategy with service levels requirements', International Journal of Production Economics, 166, pp. 72-84. doi: https://doi.org/10.1016/j.ijpe.2015.04.001.

Nunkoo, R. et al. (2017) 'Integrating service quality as a second-order factor in a customer satisfaction and loyalty model', International Journal of Contemporary Hospitality Management, 29(12), pp. 2978-3005. doi: https://doi.org/10.1108/IJCHM-11-2016-0610. 


\section{International Journal of Business Management and Economic Review}

Vol. 3, No. 03; 2020

ISSN: 2581-4664

Parasuraman, A. P., Zeithaml, V. A. and Berry, L. L. (1988) 'SERVQUAL: A multiple- Item Scale for measuring consumer perceptions of service quality', Journal of Retailing, 64(1 Spring), pp. $12-40$.

Rafiqah et al. (2018) 'Pengaruh Kualitas Pelayanan terhadap Kepuasan dan Kepercayaan Pasien Di Puskesmas Paccerakkang Kota Makassar', Window of Health Jurnal Kesehatan, 1(3), pp. 186-196.

Rainer, R. K., Prince, B. and Cegielski, C. (2017) Introduction to Information Systems. 5th edn. Wiley.

Rasyid, H. Al (2017) 'Pengaruh Kualitas Layanan Dan Pemanfaatan Teknologi Terhadap Kepuasan Dan Loyalitas Pelanggan Go-Jek', Jurnal Ecodemica, 1(2), pp. 210-223.

Santa, R., MacDonald, J. B. and Ferrer, M. (2018) 'The role of trust in e-Government effectiveness, operational effectiveness and user satisfaction: Lessons from Saudi Arabia in eG2B', Government Information Quarterly, 36, pp. 39-50. doi: https://doi.org/10.1016/j.giq.2018.10.007.

Setyo, D. and Rahmawati, D. A. (2015) 'Pengaruh Kualitas Informasi dan Kualitas Sistem Informasi terhadap Kepuasan serta Kinerja Pengguna Sistem Informasi', EFEKTIF Jurnal Bisnis dan Ekonomi, 6(1), pp. 47-59.

Siagian, H. and Cahyono, E. (2014) 'Analisis Website Quality, Trust dan Loyalty Pelanggan Online Shop', Jurnal Manajemen Pemasaran, 8(2), pp. 55-61. doi: 10.9744/pemasaran.8.2.55-61. Simamora, B. (2004) Riset pemasaran: falsafah, teori dan aplikasi. Jakarta: Gramedia Pustaka Utama.

Tjiptono, F. (2017) Strategi pemasaran. 4th edn. Jakarta: Andi.

Unidha, M. (2017) 'The Effect of Service Quality on Trust and Loyalty for Giant Customers in Malang City', Arabian Journal of Business and Management Review, 7(5), pp. 1-5.

Veeramootoo, N., Nunkoo, R. and Dwivedi, Y. K. (2018) 'What determines success of an egovernment service? Validation of an integrative model of e-filing continuance usage', Government Information Quarterly, 35(2), pp. 161-174. doi: https://doi.org/10.1016/j.giq.2018.03.004.

Widodo, A., Dwi, H. R. and Nurchayati (2016) 'Pengaruh Kualitas Sistem Aplikasi Dan Kualitas Informasi Terhadap Kepuasan Pengguna Sistem Aplikasi RTS (Rail Ticketing System) Dengan Kepercayaan Sebagai Variabel Mediasi (Studi Pada Penumpang "KAI" Ekonomi Operasi 4 Semarang)', Media Ekonomi dan Manajemen, 31(2), pp. 160-181. doi: http://dx.doi.org/10.24856/mem.v31i2.433.

Wijaya, T. (2018) Manajemen Kualitas Jasa. Ed. 2. Jakarta: Indeks.

Zeithaml, V., Bitner, M. J. and Gremler, D. (2018) Services Marketing: Integrating Customer Focus Across the Firm. 7th edn. New York: McGraw-Hill. 